4. Project activity of students of vocational schools: training course: textbook. manual / V. M. Anishchenko, MV Artyushina, TM Gerland, NV Kulalaeva, MM Shimanovsky, etc.: for general. ed. N. V. Kulalaeva. - Zhytomyr: Polissya, 2018.

5. Romanova G. M Technology of project training in the training of skilled workers // Mater. scientific-practical seminar "Didactic principles of organization of the . 2015 - Kyiv: Nat transp Univ. Inst of Profession-Techn. Education of the National Academy of Pedagogical Sciences of Ukraine. - K.: NTU, 2015.
6. Romanova G. M Theory and practice of training teachers of higher economic educational institutions for the design of educational technologies: Ph.D. Sciences: 13.00.04 / Anna Nikolaevna Romanova State Higher Educational Institution "Kyiv National Economic University named after Vadym Hetman". - K. : KNEU, 2012.

7. Romanenko Yu. A. Methodical recommendations for the course "New learning technologies": textbook. allowance. for ped students. specialties and teachers. - Donetsk : DonNU, 2009

Надійшла до редколегії 12.01.20

Kh. Bakhtyarova, Doctor of education sciences, senior lecturer, Professor

National Transport University, Kyiv, Ukraine

G. Romanova, Doctor of education sciences, senior lecturer, Professor

National Transport University, Kyiv, Ukraine

\title{
DIDACTIC PROJECTING AS A PRECONDITION FOR BUILDING UP OF THE TEACHING EXPERIENCE AMONG
} PROSPECTIVE ENGINEERS-EDUCATORS

The article deals with projecting that is an important component of the formation of a new pedagogical ideology - lifelong learning. Projecting as an educational function of the pedagogical system, becomes an important factor in human success, generating new ideas and continuous updating of outdated knowledge. It is analyzed that the practice of projecting is so widespread that in a relatively short period of time within the pedagogical system project types of work at different levels of government are actively implemented. In particular, teachers project educational programs, pedagogical technologies, including educational, upbringing, development subsystems. Thus, the preparation of teachers for design activities becomes relevant, and this in turn determines the understanding of the productive application of projecting logic, the formation of technologies for such activities.

Project activity is multifaceted and multifunctional, as it allows to form both engineering skills and abilities, as well as psychological and pedagogical. The psychological basis of didactic projecting is the readiness of the individual to constantly improve their competence, mobility of professional functions. In fact, it is a question of training at the university of an engineer-teacher-professional, competent in the main spheres of pedagogical activity.

Training of vocational training establishment students, that is aimed at developing the projecting activity related knowledge, skills, and abilities among prospective engineer-educators is supposed to essentially scale up the vocational training quality with high education establishment graduates, to foster development of their professional mobility and competitiveness in the labor market. Hence it is necessary to ensure high level of professional competence among the graduates, which, in turn, is supposed to provide for involvement of each student into high-quality educational and learning; to provide for building up the core research activity features with prospecting professionals, for building up the skills to gain individually up-front knowledge and put it efficiently into practice.

The so called educational projecting, being an option for the implementation of high-quality education concept, fully complies with the said requirements.

Keywords: didactics, project, projecting, vocational education, vocational training, vocational training establishments, prospective engineereducators.

УДК 378.147

DOI: https://doi.org/10.17721/2415-3699.2020.12.02

Н. Головко, канд. пед. наук, доц.;

В. Заруцька, магістр;

А. Черепаха, магістр

Київський національний університет імені Тараса Шевченка, Київ

\section{ІННОВАЦІЙНІ ПЕДАГОГІЧНІ ТЕХНОЛОГІЇ ЯК МЕТОД АКТИВІЗАЦІЇ ПІЗНАВАЛЬНОЇ ДІЯЛЬНОСТІ СТУДЕНТІВ У ФАХОВІЙ ПІДГОТОВЦІ}

Висвітлено різні підходи до трактування сутності інноваційних педагогічних технологій, а також проаналізовано їхній вплив на активізацію пізнавальної діяльності студентів як майбутніх фахівців. Методи активізації освітньої діяльності спрямовані на формування позитивних мотивів навчання, стимулюють пізнавальну активність і одночасно сприяють збагаченню освітньою інформації. Запровадження в освітній процес інноваційних педагогічних технологій підвищить інтерес студентів до навчання, привчить їх працювати самостійно, бути комунікативними й мобільними, адаптуватися до вимог сучасного суспільства.

Ключові слова: інноваційні педагодічні технологіі, активізація пізнавальної діяльності, фрахова підготовка, освітній процес.

Постановка проблеми. У період інтеграції закладів вищої освіти України до єдиного європейського освітнього простору педагоги все частіше звертаються до інноваційних педагогічних технологій, до творчого та креативного вдосконалення вже існуючих методів, прийомів і засобів навчання. Характерною ознакою інноваційності є здатність до оновлення, відкритість до нового. Ефективність навчальної діяльності студентів залежить від прояву пізнавальних інтересів, які спрямовують особистість на відповідну пізнавальну діяльність, ознайомлення 3 новими фрактами. До фракторів активізації навчання, безпосередньо пов'язаних із дидактичними процесами, належать насамперед методичні системи, які базуються на методах, засобах і прийомах активізації пізнавальної діяльності студентів.

Аналіз останніх досліджень і публікацій. Пізнавальна діяльність і пов'язана з нею активність розглядаються в працях багатьох вчених: Б. Г. Ананьєва, Л. С. Виготського, П. Я. Гальперіна, А. Н. Леонтьєва, Г. І. Щукіної й ін. Питання керівництва пізнавальною діяльністю відображено у працях В. В. Давидова, Л. В. Занкова, М. Н. Скаткіна, В. А. Сластьоніна, Д. Б. Ельконіна й ін. У цих дослідженнях підкреслюється, що навчання приносить успіх в активності пізнавальної діяльності завдяки сформованості продуктивної готовності майбутніх фрахівців до інноваційних перетворень. Із погляду педагогіки пізнавальна діяльність спрямована на пізнання викладачами закладу вищої освіти педагогічної діяльності, під час якого студент оволодіває не лише знаннями, але і способами їхнього набуття.

Сутність впровадження інноваційних педагогічних процесів у заклади вищої освіти стали об'єктом вивчення як зарубіжних, так і українських учених. Загальнотеоретичні і науково-практичні проблеми інноваційної парадигми у вищій 
школі, окремі сучасні форми й технології навчання досліджували А. М. Алексюк, І.І.Доброскок, Г. П. Клімова, Г. П. Коцура, С. О. Нікітчина, В. Г. Кремень та ін.

Мета статті полягає в розкритті сучасних наукових підходів щодо висвітлення змісту й основних особливостей застосування інноваційних педагогічних технологій як методу активізації пізнавальної діяльності студентів процесі фахової підготовки.

Початок дослідження проблем інноваційний педагогічних технологій припадає на кінець 50-х рр. XX ст. У вітчизняний науці поняття "інновація в освіті" з'явилось лише в середині 80-х рр. минулого століття у зв'язку із процесами перебудови радянської освітньої системи.

Тлумачення науковців поняття "інноваційна педагогічна технологія" дещо відрізняються. Так, у Законі України "Про інноваційну діяльність" інновації визначаються як "введені в обіг новостворені (застосовані) і (або) вдосконалені інноваційні продукти, інноваційна продукція, технології, продукція або послуги, результати наукових досліджень і розробок, а також організаційнотехнічні рішення виробничого, адміністративного, комерційного, маркетингового або іншого характеру, що поліпшують структуру та якість виробництва і (або) соціальної ссрери та сприяють просуванню технологій, продукції та послуг на ринок" [2. ст. 1]

І. М. Дичківська відзначає, що специфічними особливостями інноваційного навчання $€$ його відкритість майбутньому, здатність до передбачення на основі постійної переоцінки цінностей, налаштованість на конструктивні дії в обновлюваних ситуаціях [1 ].

На основі аналізу науково-методичної літератури [1-6] під інноваційними педагогічними технологіями ми розуміємо цілеспрямоване, систематичне й послідовне впровадження в практику новаторських методів, прийомів, засобів, що охоплюють цілісний навчальний процес від визначення його мети до очікуваних результатів. Це зумовлено тим, що система підготовки майбутнього фахівця має відповідати сучасним тенденціям розвитку суспільства, його запитам.

Натепер мають місце різні технології навчання, зокрема, це - проблемна технологія, ігрові, технології колективної та групової діяльності; диференційовані; інформаційні; особистісно зорієнтоване навчання; розвивальне навчання; розвиток критичного мислення; програмоване навчання; інтерактивне навчання; модульне навчання та ін.

Інноваційне навчання - це навчальна й освітня діяльність, яка ґрунтується на розвитку різноманітних форм мислення, творчих здібностей, високих соціально-адаптаційних можливостей особистості. Інновація освіти - цілеспрямований процес часткових змін, що приводять до модифікації мети, змісту, методів, форм навчання й виховання, адаптації процесу навчання до нових вимог. Інноваційне навчання - це зорієнтована на динамічні зміни в навколишньому світі навчальна й освітня діяльність, яка ґрунтується на розвитку різноманітних форм мислення, творчих здібностей, високих соціально-адаптаційних можливостей особистості. І. М. Мартинова під специфічною особливістю інноваційного навчання розуміє його відкритість майбутньому, здатність до передбачення на основі постійного переоцінювання цінностей, налаштованість на конструктивні дії в оновлюваних ситуаціях [4].

Поняття "технологія навчання" вперше було уведено відомим американським письменником і фрілософом Л. Хаббардом у 1950 р. Якщо звернутися до тлумачення поняття "технологія", то побачимо, що воно складається з двох складових: 1). "техно", що одночасно означає і мистецтво (уміння, майстерність), і ремесло (професійне заняття, професія); 2) "логія" - наука, опис. Тобто пряме значення терміна "технологія" можна тлумачити як опис, з одного боку, майстерно здійсненої професійної діяльності, а з іншого - досконалої, оптимально організованої [3].

На нашу думку, найбільш цілісним і системним є визначення С. О. Сисоєвої: "Педагогічна технологія - це процес створення адекватної до потреб і можливостей особистості і суспільства теоретично обґрунтованої навчально-виховної системи соціалізації, особистісного і професійного розвитку й саморозвитку людини, яка, внаслідок упорядкованих професійних дій педагога при оптимальності ресурсів і зусиль усіх учасників освітнього процесу, гарантовано забезпечує ефективну реалізацію свідомо визначеної освітньої мети та можливість оптимального відтворення процесу на рівні, який відповідає рівню педагогічної майстерності педагога" [5, 12]. С. О. Сисоєва відзначає поняття "педагогічна технологія" на трьох рівнях. Загальнопедагогічний (дидактичний) рівень: характеризує цілісний освітній процес у даному регіоні, навчальному закладі, на визначеному ступені навчання; педагогічна технологія розглядається на цьому рівні синомічно педагогічній системі: у неї включається сукупність цілей, змісту, засобів і методів навчання, алгоритм діяльності суб'єктів і об'єктів освітнього процесу. Частково-методичний (предметний) рівень: частковопредметна педагогічна технологія вживається у значенні "часткова методика", тобто як сукупність методів і засобів для реалізації визначеного змісту навчання і виховання в межах одного предмета, класу, учителя (методика викладання предметів, методика навчання, що компенсує, методика роботи вчителя, вихователя). Локальний (модульний) рівень: локальна технологія $€$ технологією окремих частин навчального-виховного процесу, розв'язання часткових дидактичних і виховних завдань (технологія окремих видів діяльності, формування понять, виховання окремих особистісних якостей, технологія уроку, засвоєння нових знань, технологія повторення й контролю матеріалу, технологія самостійної роботи й ін.). Розрізняють також технологічні мікроструктури (прийоми, ланки, елементи й ін.), технологічні схеми (це умовне зображення технології процесу, поділ його на окремі функціональні елементи і позначення логічних зв'язків між ними) і технологічні карти (опис процесу у виді покрокової, поетапної послідовності дій (часто у граффічній фрормі) із вказівкою застосовуваних засобів [5].

Актуальними натепер $€$ такі інноваційні педагогічні технології навчання, що використовуються у програмі підготовки майбутнього викладача. За визначенням О. П. Чубка до них належать: педагогічна технологія критичного мислення, яка полягає в тому, щоб сформувати власний погляд у студента, навчити впевнено вести дискусії та приймати виважені рішення, самостійно здобувати знання, учитись відкрито спілкуватись, логічно мислити й аргументувати; технологія навчання як дослідження, має за мету прищепити студентам навички дослідницької роботи, сформувати активну, творчу особистість; інтегральна педагогічна технологія - створює оптимальні умови для розвитку та самореалізації студента шляхом формування цілісних знань про об'єкт, що вивчається, і який є основою творення "образу світу"; технологія розвивального навчання - фрормує у студента здібності до самовдосконалення, активного, самостійного творчого мислення, самостійного навчання; технології формування творчої особистості полягає в тому, щоб прищепити студентам навички, завдяки яким вони самостійно керуватимуть своєю пізнавальною активністю, самостійно мислитимуть, приймати неординарні рішення, свідомо вибирати свою життєву позицію, 
генерувати оригінальні ідеї; технологія особистісно-орієнтованого навчання має за мету надати студенту можливість проявляти самостійність мислення, незалежність, здатність до власного вибору; проєктна технологія націлена стимулювати інтерес студентів до нових знань, до розвитку себе за допомогою розв'язання особистих проблем і використання цих знань у конкретній практичній діяльності; технологія диференційованого навчання - формує у студентів уміння вчитися, потребу в самоосвіті, виникнення TD (eB), бажання генерувати ідеї, шукати альтернативні розв'язки стандартних і проблемних ситуацій; технологія гуманістичного навчання спрямована на виховання свідомих громадян, патріотів, освічених, творчих особистостей, становлення їхнього фрізичного й морального здоров'я, забезпечення пріоритетного розвитку людини на засадах гуманізації, гуманітаризації та демократизації освітніх процесів; технологія модульно-розвиваючого навчання - формує самоосвітню компетентність студентів; технологія групового навчання - формує внутрішню мотивацію студентів до активного сприйняття, засвоєння та передачі інформації, сприяє фоормуванню комунікативних якостей студентів, активізує розумову діяльність; технології індивідуалізації процесу навчання [6].

Наявність інноваційного потенціалу педагога визначають такі чинники: творча здатність генерувати нові ідеї; високий культурно-естетичний рівень, освіченість, інтелектуальна глибина й різнобічність інтересів; відкритість особистості педагога до нового та сприйняття різних ідей, думок, поглядів, концепцій, що базується на толерантності особистості, гнучкості та широті мислення [3].

Основними принципами відбору інноваційних технологій у закладах вищої освіти є: перспективність, демократичність, гуманістичність, інтегративність, реалістичність, цілісність, керованість, економічність, актуальність. Науковці характеризують інновації за трьома основними критеріями: актуальність, корисність, реалістичність.

Виходячи з цього, І. М. Мартинова виокремлює такі критерії готовності педагога до інноваційної педагогічної діяльності:

- усвідомлення необхідності інноваційної діяльності;

- готовність до творчої діяльності;

- упевненість у тому, що зусилля, спрямовані на нововведення, принесуть позитивний результат;

- узгодженість особистих цілей з інноваційною діяльністю;

- готовність до подолання творчих невдач;

- органічність поєднання інноваційної діяльності, особистої, фахової та педагогічної культури;

- рівень психолого-педагогічної й методичної готовності до інноваційної діяльності;

- позитивне сприйняття, переосмислення минулого досвіду та його долучення до розробки інновацій [4].

Аналіз інноваційної діяльності показує, що у профресійно-практичній підготовці майбутніх викладачів, для формування їхньої фрахової компетентності впроваджуються технології, серед яких можна виділити: особистісно-орієнтоване навчання та виховання, технологію групової навчальної діяльності, інформаційні технології, проєктне навчання, теорію проблемного навчання, інтерактивні технології, технологію формування творчої особистості, теорію ігрових технологій, профрільне навчання, інтегровані технології й ін.

Для кращого розуміння інноваційних освітніх процесів та тенденцій до їхнього застосування ми провели впродовж листопада 2019 р. онлайн-анкетування студентів фракультету психології Київського національного університету імені Тараса Шевченка. Унаслідок чого нам вдалось зібрати та проаналізувати 51 заповнену анкету, що відображає незначну зацікавленість студентів у поліпшенні технологій викладання дисциплін у межах нашого факультету і складність пошуку дієвого механізму мотивації молодих людей до заповнення анкетних даних. Анкета містила 11 питань із варіантами відповідей і можливістю вписати у деяких пунктах свій альтернативний варіант.

Це дослідження змогло вкотре переконати, що інноваційна діяльність $€$ доволі специфічною, складною та багатошаровою. Тут неможливо обмежити студента чи викладача якоюсь однією технологією інноваційного навчання, методом чи формою роботи. Адже інноваційність - це, насамперед, про індивідуалізацію, про створення найбільш сприятливих умов для розвитку особистості, фрормування у неї основних компетентностей і "живих" знань. Під час впровадження будь-якої інновації ми, швидше за все, зіштовхнемось із спротивом з боку студентських груп, що $є$ цілком нормальним. Людина на підсвідомому рівні боїться всього нового, того, що їй ще не відомо - це лише працює інстинкт самозбереження. Фахівець, який прагне запровадити щось трансформоване чи модифіковане відповідно до потреб часу та суспільства в освітній процес, мусить вміти працювати з усіма можливими проявами та наслідками антиінноваційних стереотипів, організувати свою роботу так, щоб переконати більшість у користі впровадженої технології чи методики. Анкетування, яке ми провели, звичайно не є вичерпним і надалі потребує детального аналізу та корегування. Проте вже натепер ми можемо окреслити конкретні напрями роботи з розвитку інноваційного потенціалу нашого фракультету. Ми дізнались, що багато студентів не цілком задоволені якістю надання освітніх послуг, і це може впливати на їхню навчальну успішність, мотивацію до відвідування університетських занять і на рівень поваги до педагогічних кадрів. Лекція (за результатами опитування) уже віджила своє і потребує радикальних змін, які б стосувались як і стилю викладання, емоційного наповнення заняття, так і технологій викладання, які використовуються на ній.

Висновки. Отже, актуальною проблемою натепер $є$ формування нового підходу до активізації освітньої діяльності студентів у закладах вищої освіти та впровадження інноваційних педагогічних технологій у процесі фахової підготовки. Розуміння сутності цілей і завдань освіти потребує пошуку нових, інноваційних педагогічних технологій, які б забезпечували якісну підготовку фахівців відповідно до сучасних вимог суспільства. Упровадження в освітній процес інноваційних педагогічних технологій здійснює позитивний вплив на різні сфери розвитку особистості майбутнього фахівця, що доводить необхідність їхнього використання в освітньому процесі, яке допомагає активізувати пізнавальну діяльність студентів, прищепити навички творчого аналізу навчального матеріалу, під час самостійного опрацювання розв'язування проблемних питань підвищити інтерес студентів до навчання тощо. Технології сприяють ефективному засвоєнню знань, умінь і навичок, активізації та розвитку розумових дій, системи дійово-практичної сфрери, посиленню емоційності, творчої спрямованості особистості; дозволяють проявляти самостійність у прийнятті рішення; трансформуванню отриманого теоретичного досвіду у практичній діяльності, розв'язуванню ситуації з реального життя.

Список використаних джерел

1. Дичківська І.М. Інноваційні педагогічні технології : підручник ; 2-ге вид., допов. / І. М. Дичківська. - К. : Академвидав, 2012.

2. Закон Про пріоритетні напрями інноваційної діяльності в Україні від 08.09.2011 № 3715-VI (Редакція станом на 05.12.2012)

3. Енциклопедія педагогічних технологій та інновацій / упоряд. Н. П. Наволокова. - Х. : ВГ "Основа", 2009 
4. Мартинова І. М. Упровадження інноваційних педагогічних технологій як засіб розвитку творчого потенціалу педагога/ І. М. Мартинова // Нова педагогічна думка - 2016 - № 4 (88) - С. 18-22.

5. Педагогічні технології у неперервній професійній освіті : монографія / С. О. Сисоєва та ін. ; за ред. С. О. Сисоєвої. - К. : ВІПОЛ, 2001.

6. Чубко О. П. Інноваційні технології навчання в контексті педагогічної підготовки майбутнього вчителя / О. П. Чубко // Вісн. Чернігів. нац. пед. ун-ту. Педагогічні науки. - 2013. - Вип. 108/1. - Режим доступу: http://nbuv.gov.ua/UJRN/VchdpuP $2013 \quad 110837$.

References

1. Dychkivs'ka I. M. Innovatsiyni pedahohichni tekhnolohiyi: pidruchnyk / I. M. Dychkivs'ka. - 2-he vyd., dopovn. - K. : Akademvydav,2012.
2. Zakon Pro priorytetni napryamy innovatsiynoyi diyal'nosti v Ukrayini vid 08.09.2011 № 3715-VI (Redaktsiya stanom na 05.12.2012).

3. Entsyklopediya pedahohichnykh tekhnolohiy ta innovatsiy / avtorukladach N. P. Navolokova. - KH. : VH "Osnova", 2009.

4. Martynova I. M. Uprovadzhennya innovatsiynykh pedahohichnykh tekhnolohiy yak zasib rozvytku tvorchoho potentsialu pedahoha I. M. Martynova// Nova pedahohichna dumka. - 2016. - № 4 (88). - S. 18-22.

5. Pedahohichni tekhnolohiyi u neperervniy profesiyniy osviti : Monohrafiya I S. O. Sysoyeva et al / za red. S. O. Sysoyevoyi. - K. V1P0L, 2001.

6. Chubko O. P. Innovatsiyni tekhnolohiyi navchannya v konteksti pedahohichnoyi pidhotovky maybutn'oho vchytelya / O.P. Chubko // Visnyk Chernihivs'koho natsional'noho pedahohichnoho universytetu. Pedahohichni nauky. - 2013. - Vyp. 108.1. - Rezhym dostupu: http://nbuv.gov.ua/UJRN/VchdpuP 2013110837.

Надійшла до редколегії 24.11.19

N. Holovko, Ph.D, Associate Professor;

V. Zarutska, Master's student, Educational program Higher School Pedagogy;

A. Cherepakha, Master's student, Educational program Higher School Pedagogy

Taras Shevchenko National University of Kyiv, Kyiv, Ukraine

\section{INNOVATIVE PEDAGOGICAL TECHNOLOGIES AS A METHOD OF ACTIVATING THE COGNITIVE ACTIVITY OF STUDENTS IN PROFESSIONAL TRAINING}

Different approaches to the interpretation of the essence of innovative pedagogical technologies have been highlighted in the article, as well as their influence on the activation of cognitive activity of students as future specialists. It has been analysed that methods of intensification of educational activities are aimed at forming positive motives for learning, stimulate cognitive activity and at the same time contribute to the enrichment of educational information. The implementing of innovative pedagogical technologies in the educational process will increase students' interest in learning, teach them to work independently, be communicative and mobile, adapt to the requirements of modern society. It has been considered that innovative pedagogical technologies are the purposeful, systematic and consistent implementation of innovative methods, techniques, tools that encompass a holistic educational process from determining its purpose to expected results. This is due to the fact that the training system of a future specialist must comply with modern trends in the development of society, its needs.

Innovative learning is a learning and educational activity focused on dynamic changes in the world around us, based on the development of various forms of thinking, creative abilities, and high social and adaptive abilities of an individual.

In the professional and practical training of future teachers, technologies are being introduced to form their professional competence, among which are: personality-oriented education and training, group educational technology, information technology, project training, problem-based learning theory, interactive technology, creative personality formation technology, game technology theory, specialized training, integrated technologies and others.

Technologies contribute to the assimilation of knowledge and skills, the activation and development of mental actions, the system of effective practical sphere, the strengthening of emotionality, the development of a creative nature; independence in decision making; the desire to acquire skills in a relatively short period.

Keywords: innovative pedagogical technologies, activation of cognitive activity, professional training, educational process.

УДК 371.134: 3.16.2.00176

DOI: https://doi.org/10.17721/2415-3699.2020.12.03

О. Деркач, асп.

Київський національний університет імені Тараса Шевченка, Київ

\section{ЯКІСТЬ ВИЩОї ОСВІТИ ПОЛЬЩІ У ПРОЦЕСІ ТРАНСФОРМАЦІї ОСВІТНЬОї ПОЛІТИКИ}

Проаналізовано системні зміни в закладах вищої освіти Польщі за останні два десятиліття. Класична ідея стихійного суспільного розвитку та гіпотеза взаємодії формальних і неформальних закладів, яка розроблена на основі нової інституціональної освітньої політики, була прийнята як методологічна основа для аналізу й оцінки трансформації польської вищої освіти. Трансформації в польській вищій освіті є частиною більш загальних змін ролі університетів - змін, які можуть обмежити незалежність досліджень і зробити його інструментом домінуючих суспільних, політичних та економічних сил. Проаналізовано діяльність Державної акредитаційної комісії Польщі, висвітлено основні їі компетенції.

Ключові слова: вища освіта, якість освіти, трансформація, фінансування, Державна акредитаційна комісія.

Постановка проблеми. У процесі трансформації польської вищої освіти можна виділити два етапи. На першому етапі головним фактором змін став закон "Про вищу освіту" [1] від 12 вересня 1990 р., що дозволяє розвивати приватний сектор вищої освіти.

Основними досягненнями Закону 1990 р. стали: децентралізація управління вищою освітою, ліквідація державної монополії на вищу освіту й автономія ЗВО, диверсифікація системи вищої освіти - поява приватних закладів вищої освіти, виборність ректорів, свобода у визначенні навчальних програм, майнові права і свободи (університет може розпоряджатися об'єктами, що має у власності), суттєві зміни в бюджетуванні та фрінансуванні наукових досліджень, запровадження принципу конкурентності у здобутті дослідницьких грантів тощо. Варто зазначити, що громадськість отримала право й засіб контролю планів і рішень міністра, відповідального за науку та вищу освіту.

Процеси, що відбуваються на другому етапі, $є$ наслідком нового законодавства, яке впроваджує принципи Болонської програми до польської вищої освіти, а фінансове становище університету змінюється через демографрічний спад в країні. Із початку освітньої трансформації спостерігалася помітна тенденція до просування вищої освіти з дотриманням конституційного принципу безкоштовного навчання, але без значного збільшення державних витрат. Мета була досягнута завдяки розвитку приватного сектору й комерціалізації значної частини діяльності державного сектору. Труднощі та конфрлікти виявились, коли падіння попиту на послуги університету обмежувало приплив приватних коштів як до приватних, так і до державних університетів. Посилення конкуренції для студентів збіглося із впровадженням систем, спрямованих на забезпечення якості освіти. Фінансові обмеження, зростаюча конкуренція за кошти, що надходять від студентів, і система оцінювання науково-педагогічних працівників - усе це означає, що основним фокусом уваги людей та організацій, що беруть участь у навчальному процесі, $€$ формулювання університетських освітніх принципів відповідно до керівних принципів Міністерства, а потім здатність довести, що ці принципи реалізовані. 